\begin{tabular}{|l|l|}
\hline & \\
\hline &
\end{tabular}

SEÇÃO: ESTÉTICA

\title{
Dostoiévski por Adorno: a metafísica literária da vida danificada no romance $\boldsymbol{O}$ duplo
}

Dostoevsky by Adorno: the literary metaphysics of life damaged in the novel The Double Dostoievski desde Adorno: la metafísica literaria de la vida dañada en la romance El Doble

Verlaine Freitas ${ }^{1}$

orcid.org/0000-0003-0333-9416

verlainefreitas@gmail.com

Recebido em: 4 mai. 2020 Aprovado em: 18 mai. 2020. Publicado em: 28 jul. 2020
Resumo: O objetivo do texto é fazer uma análise das menções de Theodor Adorno à obra de Dostoiévski, enfatizando as relações entre a concepção do filósofo sobre a "vida danificada" e a obra literária do autor russo. Está em jogo demonstrar o quanto a "epopeia negativa" vista por Adorno em Dostoiévski se corporifica no delineamento de uma subjetividade subterrânea a partir da ideia de um excesso subjetivo fragmentado, que desemboca na ideia de má-consciência e, por fim, na falência psíquica. Tais elementos serão investigados na interpretação do romance "O duplo. Poema petersburguense", de Dostoiévski.

Palavras-chave: Theodor Adorno. Fiódor Dostoiévski. O duplo.

Abstract: The objective of the text is to analyze Theodor Adorno's mentions of Dostoevsky's work, emphasizing the relationship between the philosopher's conception of "damaged life" and the Russian author's literary work. It is at stake to demonstrate how much the "negative epic" seen by Adorno in Dostoevsky is embodied in the delineation of an underground subjectivity from the idea of a fragmented subjective excess, which leads to the idea of bad conscience and, finally, to psychic bankruptcy. Such elements will be investigated in the interpretation of the novel "The double. Petersburg poem ", by Dostoevsky.

Keywords: Theodor Adorno. Feodor Dostoevsky. The double.

Resumen: El objetivo del texto es hacer un análisis de las menciones de Teodoro Adorno de la obra de Dostoievski, haciendo hincapié en las relaciones entre la concepción del filósofo de la "vida dañada" y la obra literaria del autor ruso. Está en juego demostrar lo mucho que la "epopeia negativa" vista por Adorno en Dostoievski encarna en el diseño de una subjetividad subterránea a partir de la idea de un exceso subjetivo fragmentado, que conduce a la idea de mala conciencia y, finalmente, el fracaso psíquico. Estos elementos serán investigados en la interpretación de la novela "El doble. Poema petersburguense", de Dostoievski.

Palabras clave: Theodor Adorno. Phytodor Dostoievski. El doble.

"[...] os grandes escritores, sem exceção, fazem suas combinações em um mundo que vem depois deles, como as ruas parisienses dos poemas de Baudelaire só existiram depois de 1900 e também não antes disso os seres humanos de

Dostoiévski".

(Walter Benjamin, Einbahnstraße) 
A obra literária de Fiódor M. Dostoiévski possui um inegável conteúdo filosófico. ${ }^{2}$ Textos como O duplo, Memórias do subsolo e Crime e castigo apresentam grande densidade conceitual, abordando temas cruciais como alteridade, livre-arbitrio, individualidade, utilitarismo moral, culpa, racionalidade, ressentimento, má-consciência etc. Apesar de Theodor Adorno ter escrito muitos artigos filosóficos sobre literatura, suas observações sobre o autor russo são pontuais e esparsas, sem desenvolvimento específico. ${ }^{3}$ Apesar dessa precariedade de referências, as questões mobilizadas por elas são suficientemente ricas e instigantes para merecerem um comentário capaz de lançar luz à obra de Dostoiévski e, neste artigo focalizaremos especificamente o romance $O$ duplo. Poema petersburguense, o segundo publicado pelo autor.

Além da estética de Adorno, nossa análise baseia-se na teoria psicanalítica de Sigmund Freud. No primeiro caso, não se trata de uma "aplicação" da teoria adorniana, mas sim da proximidade a seu modus operandi dialético e do aproveitamento de temas e conceitos centrais, como subjetividade, razão, vínculo entre indivíduo e sociedade, papel da experiência estética nos processos de subjetivação e a crítica às relações de poder. No segundo caso, pretendemos evitar três tipos de abordagem típicos: 1) tomar a obra literária como ilustração e exemplo de formulações conceituais psicanalíticas 4 ; 2) analisar a pessoa-autora por meio dos personagens e da trama narrativa da obra; ${ }^{5}$ 3) ler uma ou mais personagens como se fossem pessoas empíricas, propondo uma interpretação nos mesmos moldes de uma interpretação clínica real $^{6}$. Cada uma dessas estratégias pode trazer elementos hermenêuticos válidos e úteis para a elucidação do fenômeno estético-artístico, a depender do grau e da forma de abertura ao teor ficcional e poético da obra literária, mas, em seu conjunto, demonstram um interesse investigativo preocupado com questões alheias a esse foco, sendo-nos pouco recomendáveis como pontos de apoio principais.

Dostoiévski possui uma vasta obra literária, com alguns livros extensos e cuja hermenêutica filosófica demanda uma longa investigação. Cremos que a análise apresentada neste artigo se mostra adequada especialmente para interpretar os textos O duplo, Memórias do subsolo e Crime e castigo, cuja nucleação temática preponderante é o que chamamos de "subjetividade subterrânea", exemplarmente delineada no primeiro e segundo livros. O ponto de fuga do percurso literário a concepção estético-literária do indivíduo como dramaticamente alheio ao complexo societário vivo, começando com as vicissitudes do personagem Golyádkin e sua falência psicossocial, passando pelo pântano do homem do subsolo e seu complexo moral hipertrofiado no ressentimento e na má-consciência, até o complexo mortífero de Raskólnikov e sua autoconcepção

\footnotetext{
2 Essa característica é ressaltada por vários comentadores, como, por exemplo, Tzvetan Todorov, Joseph Frank, James Scanlan e Georg Lukács.

3 A principal motivação, ao que nos parece, é o fato de Adorno somente ter escrito comentários mais longos sobre obras literárias escritas nos idiomas conhecidos por ele, o que não é o caso do russo.

4 Estratégia praticada pelo próprio Freud em sua interpretação das obras de Dostoiévski em "Dostojewski und die Vatertötung" ["Dostoiévski e o parricídio"] e da tragédia de Sófocles Édipo-Rei.

Essa forma de abordagem é recusada, entre outros, por Vladimir Safatle, sob o argumento crítico de ela tomar a arte como prestando um serviço à psicanálise e, assim, retirar-lhe seu caráter próprio (SAFATLE, 2006, p. 165). Fizemos uma abordagem pormenorizada dessa questão em FREITAS, 2017, p. 119-121.

5 Prática também de Freud no mesmo artigo citado sobre Dostoiévski, bem como ao propor uma análise de Leonardo da Vinci por meio de sua obra pictórica (FREUD, 1999b); cf. também BREGER, 1989, que faz uma extensa leitura das vicissitudes psiquicas do autor russo vinculando dados biográficos às obras produzidas em cada período.

Esse tipo de abordagem foi enfaticamente rejeitado por Adorno em vários momentos de sua estética, como, por exemplo, ao dizer: "somente diletantes fundamentam tudo da arte no inconsciente. [...] No processo de produção artístico, as moções inconscientes são impulso e material em meio a vários outros. Elas entram na obra de arte mediadas pela lei formal; o sujeito literal produtor da obra seria nela nada mais que um cavalo pintado. Obras de arte não são thematic apperception test de seus autores" (ADORNO, 1997a, p. 21, tradução nossa). Todas as traduções das passagens citadas de Adorno são de nossa autoria.

6 Essa forma de leitura foi adotada por Bernard J. Paris em seu Dostoevsky's Greatest Characters: A New Approach to "Notes from Underground," "Crime and Punishment," and "The Brothers Karamazov", principalmente a partir da psicanálise de Karen Horney. O titulo do livro já indica o foco da análise: os "characters", as personagens, e não propriamente o enredo, a trama ou a linguagem literária. No caso do homem do subsolo, analisou-se o protagonista como se se tratasse de uma narrativa real de uma pessoa real, descurando quase completamente do teor ficcional da obra.
} 
de um pseudo-super-homem nietzschiano.?

As referências mais significativas da obra de Dostoiévski na estética de Adorno estão no texto "Standort des Erzählers im zeitgenössiscen Roman" ["A posição do narrador no romance contemporâneo"]8. Elas ocorrem em meio a uma reflexão sobre a origem do romance que liga Schiller, com sua distinção entre poesia ingênua (dos gregos) e sentimental (dos modernos), passando por Hegel, com sua ideia da "prosa do mundo" - quando o indivíduo se vê particularizado em busca de fins dispersos e não conectados em um mundo coeso, à distinção do mundo antigo - passando também por Georg Lukács e sua teoria do romance como contraposição moderna à objetividade do epos antigo, até a concepção de Walter Benjamin da impossibilidade de troca de experiências por meio de narrativas, devido ao definhamento da própria capacidade de se fazer experiências. ${ }^{9}$ Em seu conjunto, esses autores, ressalvadas as diferenças de concepção e de objetos de análise, delineiam a contraposição entre o mundo unitário, coeso e dotado de sentido da antiguidade clássica, cuja imbricação entre ser humano, natureza e deuses implicava um senso de imediatidade para a vida, por um lado, e o mundo moderno, por outro, com sua fragmentação, relatividade de fins, crescente individuação e reflexividade, quando as obras literárias não apenas testemunham uma perda de sentido pré-dado, quanto ainda inserem em suas formas momentos reflexivos como modo de exprimir a busca por um sentido.

\section{A dialética intrínseca da forma romance}

A ênfase inicial de Adorno no texto "A posição do narrador no romance contemporâneo" é a impossibilidade de o sujeito narrar(-se) em meio ao mundo caótico e destituído de legitimação suficiente no horizonte sombrio do capitalismo.
O discurso literário supõe uma objetividade do mundo vivido com alguma estabilidade de sentido, capaz de o configurar como ob-jeto propriamente dito, mas a experiência desiludida pelas relações de poder consubstanciadas na vida concretamente capitalista implica transformar a literatura em um documento da inviabilidade de sua pretensão. Como saida, o romance pratica, a seu modo, uma forma de "abstração" (um tanto análoga ao da pintura): o abandono do desiderato de açambarcar o real-vivido e mergulhar, seja no redemoinho dos paradoxos subjetivos, seja na força poética das formulações linguísticas; Dostoiévski é um exemplo paradigmático do primeiro caso, e James Joyce, do segundo. Do realismo do mundo-representado, passa-se para a realidade do sujeito e sua potência formadora, cuja ubiquidade se transmuta na qualidade poética por excelência.

O ato de narrar pressupõe não apenas a continuidade da experiência e da vida como algo dotado de sentido, mas também a possibilidade de se ler nela um significado particular, com o poder de levantar uma questão própria, conduzindo a forma literária a se desdobrar com seus meios para formular tal questionamento. A onipresença das relações de troca, porém, transforma o mundo em um sempre-igual, nivelando a tudo e a todos na maquinaria de uma fungibilidade universal: tudo tende a ser medido por sua capacidade funcional, perdendo sua diferença qualitativa. Ao insistir no desiderato de narrar uma parte do mundo como significativo, o romance pode resultar em um descolamento fictício perante a onipotência das formas racionais de concepção de mundo.

Se a objetividade do mundo escapa à pretensão narrativa, o âmbito psicológico não fica imune aos dispositivos científicos capazes de transformá-lo em um objeto legivel segundo leis, hipóteses e conceitos próprios, cuja consequência é também reduzir sua qualidade própria como objeto do

\footnotetext{
7 Embora seja corrente interpretar o protagonista de Crime e castigo em analogia ao Übermensch de Nietzsche, concordamos com John Carrol quando afirma: "Raskólnikov não fornece uma prova para a rejeição do egoísmo como um tipo humano viável. Sua pose napoleônica representa um exemplo da vontade de potência que Nietzsche não teria aprovado: ela contém muitos traços da moral dos escravos" (CARROL, 1988, p. 146, nota, tradução nossa.

8 Trata-se do terceiro capítulo das Noten zur Literatur I ["Notas sobre literatura I"] (ADORNO, 1997e).

9 Cf. SCHILLER, 2002; HEGEL, Georg W. F., "Die Abhängigkeit des unmittelbaren einzelnen Dasein"; HEGEL, 1986; LUKÁCS, 1971; BENJAMIN, 1997.

Sobre o arco conceitual unindo Hegel, Lukács, Benjamin e Adorno, cf. David Cunningham, "After Adorno: The Narrator of the Contemporary European Novel".
} 
romance. O exemplo dado por Adorno é precisamente o de Dostoiévski: sua acuidade em discernir a profundidade da alma humana, que levou Nietzsche a considerá-lo o único psicólogo com algo a the ensinar ${ }^{10}$, teria sido suplantada pela eficácia da teoria psicanalítica. Enquanto no autor russo, porém, o âmbito psíquico se manifesta em sua força como uma realidade de direito próprio, subjetivamente carregada e pujante, na teoria psicanalítica o sujeito seria transformado em um objeto cognitivo e terapêutico de forma análoga a como a força de trabalho é reificada nas condições capitalistas ${ }^{11}$. O real mérito de Dostoiévski, porém, sua qualidade progressista, não residiria propriamente na perspicácia da elucidação psicológica de nós, seres humanos reais, mas sim do "caráter inteligivel", da essência humana. Análogo a como Aristóteles havia afirmado a superioridade da poesia perante a história por se dirigir ao universal, enquanto esta última se restringe a descrever como o particular ocorreu, Adorno situa a psicologia de Dostoiévski em um patamar de veracidade distinto das ciências psicológicas. Somente em um plano de negação da realidade factual pode o romance fazer justiça a seu desiderato de realismo, pois a empiria determina-se cada vez mais pela força da alienação entre sujeito e mundo, entre individuo e sociedade, impregnando cada fotograma do real com a mesma falsidade sedimentada nas coisas pelas relações ancestrais de poder. A própria alienação monadológica subjetiva é trazida para o tecido literário, tornando-o metafisico, colocado além da empiria das relações concretas, tornadas por demais abstratas em função de sua fungibilidade capitalista: "se o romance pretende permanecer fiel a sua herança realista e dizer como o mundo de fato é, então ele precisa renunciar a um realismo que, ao reproduzir a fachada, auxilia-a em sua atitude mistificadora" (ADORNO, 1997e, p. 43, tradução nossa).

No extremo peso da realidade socioempirica à nossa compreensão, resta ao romance uma terceira via de denúncia emancipadora, além do aprofundamento psicológico e da torção poética de sua linguagem, a saber: a intromissão do discurso autoral em primeira pessoa na ficção, o desnudamento metaliterário da narrativa, a suspensão da distância estética por meio do comentário não apenas sobre personagens (como já se fazia em romances pré-modernos), mas sobre a própria pessoa-autora, fazendo o leitor participar da construção da obra. Esse recurso de infiltração reflexiva no romance é tomado com reservas por Adorno: "há razão para se supor que, quando ela ocorre, como nos grandes romances de Hermann Broc, não favorece a composição literária" (ADORNO, 1997e, p. 44, tradução nossa). O exemplo de fusão sem ressalvas entre a narratividade e o teor reflexivo dado por Adorno (1997e, p. 45) é Em busca do tempo perdido, de Marcel Proust, mas, se levarmos a sério a muito celebrada concepção de polifonia dialógica de Mikhail Bakhtin, exposta em Problemas da poética de Dostoiévski, podemos dizer de um lugar único para o autor russo nesse aspecto.

Segundo Bakhtin, embora haja antecedentes importantes, Dostoievski foi o criador do romance polifônico, dialógico, que entrelaça várias vozes interdependentes, mas com sua autonomia relativa, fazendo cada uma delas se completar na outra e ser também o complemento dela. A obra monológica situa cada fala, personagem e ação no horizonte macro do ponto de vista do autor, onde tudo adquire sentido, justificação e finalidade em um mundo ordenado e que se basta a si mesmo. O romance polifônico, ao contrário, não figura, não constitui, um ser humano em sua objetividade (incluindo suas dúvidas, hesitações e incertezas), mas sim o "homem no homem", ou, e em outras palavras, toma como seu material a humanidade do ser humano, questionando sempre os pontos de apoio para sua própria identidade, para o complexo ideativo de seu ser. A obra literária polifônica é um "romance ideológico", cada uma posta em situação de incompletude, de tal forma a fazer seu personagem invocar a ideia alheia como

10 "Dostoiévski, o único psicólogo [...] do qual eu tive algo a aprender: ele pertence às mais belas ocasiões felizes de minha vida [...]" (NIETZSCHE, 1999c, §45).

11 Essa crítica de Adorno à psicanálise é feita no aforismo de número 49 das Minima Moralia, à qual propomos uma resposta em um capítulo de livro a ser publicado em breve. 
fermento, contraposição e limite de sua visão de mundo (BAKHTIN, 1997, p. 22). Uma personagem de Dostoievski é um ideólogo, atravessando todo o enredo como um labirinto de questões, pontos de vista, imagens de mundo etc. Os protagonistas não são apresentados no desenvolvimento histórico-genético de suas ideias, mas sim como quem já possui uma concepção plena do que the sucede. As personagens relacionam-se propriamente como seres de ideias, e não de ação, mesmo quando o agir é posto como objeto temático explícito. Isso é válido para a caracterização de cada uma delas, pois interessa bem mais a percepção de cada uma sobre si, sua autoconsciência, e menos suas propriedades objetivas, sua situação social e política, suas posses etc. Trata-se de personagens essencialmente valorativas, cujo ponto de apoio para a narrativa é sua autoimagem ideativa: são por assim dizer "personagens de segunda ordem" (BAKHTIN, 1997, p. 48). ${ }^{12}$

\section{Dostoiévski: uma epopeia negativa}

A dimensão polifônica, aberta e inconclusa vista por Bakhtin na polifonia de Dostoiévski e a metafísica literária auto-negadora da aparência estética concebida por Adorno para o romance moderno convergem na ideia de uma forma de romance autossuperadora, extraindo de seus limites e contradições os principios de uma nova configuração literária. Esse complexo artístico-cultural já havia movido a Lukács em suas reflexões sobre a possibilidade de uma nova forma de epopeia, para além do romance desiludido do final do século 19. Nas páginas finais de sua Teoria do romance, ao analisar a obra de Liev Tolstoi, o autor afirma:

A ultrapassagem da cultura apenas a incinerou, não tendo colocado em seu lugar nenhuma vida mais segura ou mais essencial; a transcendência da forma romance torna-a mais problemática [...], sem se acercar, mais que outras formas, do objetivo almejado, a saber: a realidade não-problemática da epopeia em uma configuração concreta (LUKÁCS, 1971, p. 136). ${ }^{13}$
As produções literárias dessa época mostraram-se fragmentárias, sem a suficiente consistência, retomando aqui e ali configurações ultrapassadas, sem apresentar a necessária força produtiva. Nem mesmo as obras de Tolstoi foram capazes de alcançar essa transcendência do romance por si mesmo, pois, apesar de se vislumbrar nelas uma nova configuração literária de um mundo além da pecaminosidade moderna (segundo uma expressão de Fichte retomada por Lukács), elas permanecem "polêmicas, nostálgicas e abstratas" (LUKÁCS, 1971, p. 137) ${ }^{14}$.

Em contraste a esse estado de coisas, a obra de Dostoiévski é celebrada como se situando em um novo patamar:

Dostoiévski não escreveu romances, e a concepção formadora tornada visivel em suas obras não tem nada a ver, seja afirmativa ou negativamente, com o romantismo europeu do século 19 e com as múltiplas e também românticas reações a esse romantismo. Ele pertence ao novo mundo. (LUKÁCS, 1971, p.137). ${ }^{15}$

Apesar dessa ênfase no caráter inovador das obras de Dostoiévski, Lukács se pergunta se elas já constituem de fato e de direito uma nova forma de epopeia ou se configuram um presságio, produzindo as canções a serem reunidas e amadurecidas por outras gerações literárias. A resposta de Adorno é instrutiva: trata-se de uma "epopeia negativa" (ADORNO, 1997e, p. 47), característica estendida por ele a outros grandes romances. Essas obras são marcadas por serem documentos de uma época de declínio da subjetividade, seja isso índice de progresso ou de recaída na barbárie. De qualquer forma, a arte verdadeiramente progressista não se resguarda quanto ao papel a desempenhar nessa política conflituosa do particular impotente e a coletividade onipotente: resta-lhe entretecer configurações capazes de pôr em xeque a inércia do sempre-igual, movendo-se nas formas arcaicas e pré-egóicas da individualidade para vislumbrar dialeticamente a superação do estado de coisas

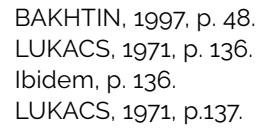


atual. A poética de Dostoiévski move-se precisamente nesse campo de forças. Na Filosofia da nova música, Adorno afirma:

A categoria do sujeito não estava tão rigidamente configurada na Rússia pré-burguesa quanto estava nos paises ocidentais. A estranheza de Dostoiévski provém da não-identidade do eu consigo mesmo: nenhum dos irmãos Karamazov é uma 'personagem'. ${ }^{16}$

Situando-se nesse limiar da dissolução do sujeito, expondo de forma drástica a incompossibilidade entre particular e universal, as grandes obras de arte tornam-se expressivas por dar voz à dissonância e ao sofrimento vivido como preço do individuo em sua luta por se diferenciar do aniquilamento no sempre-igual das formas coletivas de poder. Presa das formas sociais de subjugação, a individualidade vive uma "vida danificada", quando o "narcisismo, cujo objeto libidinal the é retirado devido à ruina do eu, é substituido pelo prazer masoquista de não ser mais um eu" (ADORNO, 1997d, §40, tradução nossa). Ao mesmo tempo, porém, o investimento egóico permanece, pois no estado atual das regressões, "o eu é simultaneamente negado e enrijecido de forma falsa e irracional" (ADORNO, 1997g, p. 110, tradução nossa). Somando-se as duas tendências, chegamos a um enigmático "narcisismo masoquista" - conceito útil para se analisar as Memórias do subsolo. Para Dostoiévski vale plenamente o afirmado por Adorno sobre Proust: "o narrador constitui por assim dizer um espaço interior que o resguarda do passo em falso no mundo alheio, que se revelaria na falsidade do tom que nos torna familiares a esse mundo."17 - O segundo romance publicado por Dostoiévski, O duplo, constitui um dos momentos da configuração hiper-dramática desse espaço interior, conduzindo-nos por uma verdadeira epopeia negativa - passemos a ela.

\section{A dessubstantivação do sujeito: falência social e ruptura egóica em $O$ duplo}

Como ressaltado pela tradição de comentários, a obra de Dostoiévski está permeada de temáticas ligadas à duplicidade das personagens..$^{18}$ Iniciando de forma positiva, como objeto e tema principal, em $O$ duplo, esse fenômeno retornará em obras posteriores, seja de forma sutil, como na relação entre Raskólnikov e Svidrigáilov, até sua reaparição explícita na alucinação de Ivan Karamázov. Nesse cenário, a duplicidade não constitui apenas o objeto da representação estética, mas também um dispositivo, uma estratégia discursivo-literária para invocar tensões narrativas, colocar frente a frente discursos antagônicos e simultaneamente complementares, questionar o caráter ilusório da busca pela unicidade etc. Em função disso, a cada momento surgem planos diferentes de duplicação, de rebatimento, de correlações especulares cuja interpretação abre novas leituras da interação das vozes-ideias de cada protagonista. Nesse sentido, trata-se de uma espécie de concretização, como material poético, do princípio da polifonia concebido por Bakhtin. Sendo o romance um tecido polifônico, fundado nesta multiplicidade de ideias-discurso a um só tempo autônomas e interdependentes, não causa surpresa detectarmos não apenas microdiálogos em cada fala dos protagonistas, mas uma divisão de seu próprio eu, de sua personalidade, de seu ser, quando então esta por assim dizer "vibração polifônica" encontra uma consubstanciação dramática na luta esganiçada das personagens para se afirmarem no instante de sua ruptura, mas não simplesmente esfacelamento, em virtude de a figuração da duplicidade ainda exprimir, personificar, incorporar o desiderato de afirmação de si.

Nosso objetivo é fazer uma interpretação dos múltiplos planos e modos de atualização presentes em 0 duplo. Desde as primeiras páginas deste

\footnotetext{
16 ADORNO, 1997f, p. 134, nota, tradução nossa. A última palavra da passagem citada é "Charakter", cuja tradução pode ser "personagem", mas também "caráter", tal como se usa em português para denotar a personalidade; as aspas certamente indicam a intenção de Adorno em ressaltar a ambiguidade. Assim, cada um dos Karamazov não teria propriamente a unidade típica do caráter capaz de lhe conferir uma unidade pessoal e, portanto, de lhe constituir como indivíduo.

17 ADORNO, 1997e, p.44, tradução nossa. Há ainda outro contexto com algumas referências diretas de Adorno a Dostoiévski, ao ligá-lo à música de Gustav Mahler (Cf. ADORNO, 1997c). Como, porém, em tal vinculo o objeto de elucidação é a música e não a literatura, deixaremos essa temática para outro contexto argumentativo.

18 Cf., por exemplo, CHIZHEVSKY, 1962; RENAUX, 1976.
} 
"poema petersburguense", vemos elementos de duplicidade no caráter anímico - quase fantasmagórico - do cenário e dos objetos pessoais do protagonista: "o dia cinzento de outono, turvo e enlameado, espiou pela vidraça embaçada de sua janela com um ar tão zangado e uma careta tão azedal...]" (DOSTOIÉVSKI, 2011, p. 9); "É provável que o maço de notinhas verdes, cinzentas, azuis, vermelhas e outras notinhas multicores também tenha olhado de um jeito muito amável e aprobativo para o senhor Golyádkin" (DOSTOIÉVSKI, 2011, p. 11); "[...] vendo-se apenas um samovar preparado ali no chão, zangado, irritado, fora de si, ameaçando continuamente transbordar e matraqueando com fervor alguma coisa em sua linguagem esdrúxula, velarizando e ciciando para o senhor Golyádkin, talvez querendo dizer: pegue-me, boa alma, pois já fervi tudo o que tinha que ferver e estou pronto (DOSTOIÉVSKI, 2011, p. 11)". Como mostrou de forma convincente Mikhail Bakhtin (1997), a voz do narrador se separa e se entrelaça à do protagonista, muitas vezes apenas antecipando ou repetindo suas falas, outras vezes caçoando de seu caráter ridículo, configurando ele mesmo um duplo para o nosso herói. A voz da consciência de Golyádkin contém um peso narrativo e uma densidade de enunciação discursiva suficientes para demarcar uma protoduplicidade, a se desdobrar e adquirir realidade substantiva na projeção psicótica. O fato de, mesmo sendo um funcionário público de baixo escalão, ter dinheiro suficiente para manter um criado indicaria a acentuação de Pietruchka também como um duplo, um coabitante incessantemente interpelado, agredido e solicitado ao longo da narrativa.

O fio condutor mais geral do conceito da duplicidade, cujas vicissitudes impulsionam este tema-dispositivo e objeto-estratégia, é a tensão inerente à afirmação da identidade em comércio com o plano social e interagindo com ele, particularmente concernindo à ponte ético-moral destes dois extremos do processo de subjetivação e, neste mesmo passo, de socialização. Figurando como uma espécie de macroduplo, o âmbito social apresenta-se como um polo atrator do questionamento dos valores íntimos, ao mesmo tempo demarcando o tribunal e o cadafalso da execução derradeira do sujeito. 0 complexo dos valores possui grande viscosidade existencial, enredando o sujeito em um torvelinho de contradições, expectativas, demandas, recusas e condenações suficientemente fortes para constituir o palco e o cerne gravitacional da bipartição e falência subjetiva.

Esta teia de elementos ético-morais não será focalizada por Dostoievski em um plano de abstração comparável a enunciações filosóficas ou mesmo psicanalíticas, mas sim em sua incorporação viva na constituição singular, pessoal. No caso de O duplo, como ocorre em quase todos os textos de Dostoiévski antes de sua prisão, a personagem principal é um funcionário de baixo escalão da enorme e ramificada burocracia da Rússia czarista. Não se trata propriamente de miseráveis, nem de pessoas de classe média, mas de indivíduos decaídos, no limiar da pobreza e da cidadania em sentido mais propriamente burguês, capitalista. Essa demarcação da individualidade antecipa a de Kafka, que focaliza os estratos inferiores das classes médias também entrelaçadas no labirinto de uma burocracia insana. Enquanto o escritor tcheco, porém, aborda um momento radical de desagregação da subjetividade, constituindo uma "epopeia expressionista", 19 acusadora do peso ancestral-mítico da ordem societária sobre o individuo impotente, em Dostoievski temos a insistência em focalizar o sujeito como uma condição-limite, como trânsito descompassado entre sua interioridade moral e a exterioridade objetiva do palco social e político. Vemos aí um ponto de inflexão, crítico e questionador, niilista e utópico, cético e humanista, entre a ilusão da inteireza da individualidade e a queda na subjetividade: situamo-nos na exposição contínua desta arqueologia do homem subterrâneo, daquele sabedor de si por meio de um sulco moral que vinca sua epiderme simbólica, convencendo-o do caráter vão e ridículo de seus esforços de ser si mesmo e de transcender o círculo de sua egoidade. Em vez de uma epopeia expressionista kafkiana, mais valeria - seguindo a ideia de Adorno -, um

19 ADORNO, 1997b, p. 278; fizemos uma análise dessa noção em nosso artigo (FREITAS, 2017); cf. também FOSTER, 2013). 
epos negativo, quando a interioridade se cinde e, no emaranhado de seus questionamentos infinitos, constitui-se de forma precária.

Nessa correlação pendular entre o interior subjetivo-moral e a exterioridade ético-política, um conceito nuclear é o de descompasso, de antecipação fracassada e de resgate insuficiente. Qual uma paródia burlesca da decisão urgente dos personagens de uma tragédia, o protagonista sempre se situa em uma perspectiva moral altamente instável, não apenas falivel, mas marcada por uma cegueira tão radical relativa às suas motivações, que repete incessantemente fórmulas de salvação e juizos morais terminativos a cada instante. Oscilando entre a insistente autoproteção moral e a acidez das acusações de vilania a outrem, Golyádkin parece ter certeza apenas da impossibilidade de ter certeza, ${ }^{20}$ ou, no limite, somente estar seguro quando renuncia a toda e qualquer esperança de validade para seus juizos morais.

Se Freud havia dito que o fundador da civilização foi quem depôs as armas e desferiu o primeiro insulto, Dostoiévski parece figurar esta derivação metafórica no sentido de fazer o personagem aderir íntima e dramaticamente à rede de seus valores morais: sua vida praticamente recobre sua altura-imagem moral. Acusar, julgar, condenar, xingar, ofender equiparam-se à morte do outro no plano moral, e o mesmo vale, mutatis mutandis, para as escusas, justificativas, perdões, reconsiderações: modos de conservar uma vida em perigo, incerta quanto à sua continuidade, sua legitimidade de persistir, de ocupar um espaço na ordem da existência cósmico-coletiva. Um dos princípios da dramaticidade da obra comentada por nós consiste no fato de a substância moral do protagonista mostrar-se uma verdadeira areia movediça, indice muito mais de sua perdição que de seu apoio. Quanto mais a personagem revolve e se debate com esta absorção de seu eu por este pântano moral, mais suas energias são consumidas e fazem fermentar a substância que irá asfixiá-lo. - Aqui, mais uma vez, vale de forma dramática a ideia que Adorno recupera de Hegel, Schiller, Lukács e Benjamin da impossibilidade de narração, agora trazido para o âmbito do personagem, ou seja, como elemento material interno à obra: tudo o que o protagonista mobiliza para conferir inteireza ao relato sobre si esfacela-se.

Cabe salientar um princípio geral de ética filosófica tornada muito clara a partir das concepções modernas, a saber: os preceitos éticos configuram eles mesmos uma camada de duplicidade em relação ao indivíduo singular, instituindo um plano abstrato, despersonalizado, pairando sobre o sujeito sem possibilidade de diálogo interno, vivo, suficientemente concreto em termos simbólicos para tornar possivel a compreensão do indivíduo como tendo sua razão de ser em sua singularidade, em sua verdade subjetiva, e não apenas como um dos infinitos casos de aplicação de preceitos não apenas gerais, mas dolorosamente genéricos. Em grande medida, as concepções éticas contrárias ao racionalismo da ética kantiana, dentre as quais ressalte-se de Nietzsche, procuram mostrar a dignidade ético-moral do indivíduo em sua singularidade. A esfera moral, como um conjunto de preceitos gerais de ação, entretanto, persiste no registro abstrato, baseando-se em noções às vezes até mais radicalmente diluidoras do singular em um plano indiferenciado, como se pode interpretar o princípio do eterno retorno nietzschiano.

A densidade propriamente ético-moral do sujeito como uma condição-limite cresce em complexidade ao longo da obra de Dostoiévski. Ela já se faz presente nas primeiras obras, mas não como alvo do questionamento literário, e sim como matéria e solo poético do qual emergem as figuras e imagens dramáticas.

A vida psicoemocional de Goliadkin é pautada pelo excesso, pelo desdobramento enovelado, rebatido, em meio a um redemoinho centrípeto e centrífugo. A multiplicidade de suas representações mentais vincula-se tanto a uma fragmentação endógena quanto uma agregação exógena, forçando a implicação regressiva da alteridade social em seu complexo afetivo, um movimento marcado de antemão por substituir o sentido objetivo por um que é, a bem dizer, pré-subjetivo, inconsciente.

2o Essa ideia é de Sigrid Renaux (RENAUX, 1976). 
Um principio subjetivo relevante na fermentação deste excesso fragmentário é o fato de Golyádkin sofrer de má consciência aguda, como vemos em inúmeras passagens, quando o protagonista age sob um impeto fraco, hesitante, prestes a se desfazer e já propenso a se justificar:

[...] será que tudo isso está certo? Será decente? Será oportuno? De resto, que importa? - continuou ele, subindo a escada, tomando fôlego e contendo as batidas do coração, que tinha o hábito de bater em todas as escadas alheias que importa? ora, vou tratar de assunto meu e nisso não há nada de censurável... Seria uma tolice eu me esconder. Darei um jeito de fazer de conta que vou indo, que entrei por entrar. que estava passando ao lado... E ele verá que é assim que deve ser... (DOSTOIÉVSKI, 2011, p. 17);

Sentia que agora tinha a real necessidade de tomar alguma decisão; sentia até que pagaria muito a quem lhe dissesse exatamente que tipo de decisão deveria tomar. Ora, pois, como hei de adivinhar? Pensando bem, não havia tempo para adivinhar (DOSTOIÉVSKI, 2011, p. 127-128).

O conceito de má consciência foi trabalhado por Nietzsche em sua Genealogia da moral, significando uma incerteza quanto aos principios e motivos da escolha, implicando uma incapacidade por vezes desesperadora para avaliar a correção moral de cada ato e também uma constante consciência culpada. Esta última decorre da virtual impossibilidade e de o sujeito se reconhecer como principio motor tanto das decisões quanto das avaliações retrospectivas. Não se trata propriamente de má-fé, compreendida como negação sistemática de verdades inerentes à decisão, mas sim de uma incapacidade de se identificar aos valores constituintes da rede moral subjetiva. Embora os conceitos de má consciência e culpa não equivalham, são muito dificeis de distinguir, pelo fato de o primeiro sempre implicar o segundo, dada a impossibilidade de isenção do sujeito como principio causador de ações transgressores. $O$ agente tende a flutuar em seu pensamento de: "quem sou eu neste processo de decisão?". Segundo Nietzsche (1999b), em virtude de mecanismos complexos e historicamente arcaicos de introversão da força e do desejo transgressi- vo, o individuo experimenta uma multiplicidade de impulsos e de direcionamentos valorativos, muito pouco concordantes e no mais das vezes contraditórios. Uma mesma ação, assim, pode ser vista como excessivamente moral, sob um determinado impulso, mas imoral sob outro, momento em que, independente de quaisquer avaliações objetivas, "algo" no sujeito cobrará punição por uma ruptura moral. Claro está tratar-se de uma desordem subjetiva, uma espécie de caos ético-moral quase impossivel de obter resolução satisfatória. Dentre essas resoluções inatingiveis, uma delas é responder a ofensas: "E enquanto o senhor Golyádkin já ia começando a quebrar a cabeça querendo saber por que era mesmo tão dificil protestar ao menos contra tal piparote" (DOSTOIÉVSKI, 2011, p. 154), pois o sujeito não consegue estabelecer um ponto de apoio para se justificar, para dizer de si como violentado, para afirmar e firmar sua honra. O quanto a ofensa terá sido justa e... desejada pela vítima?

Para dar conta dessa efervescência caótica e descompassada, o sósia será a consequência inexorável que concretiza de forma espetacular - e isso tanto no plano literário quanto sob a perspectiva do protagonista - a necessidade de duplicar o espaço psíquico de modo a fazer caber o excesso fragmentado. Só que essa duplicação é também uma cisão, como que um pseudópode excisado do corpo psíquico do personagem. O duplo figura, então, como uma derivação metafórica da personagem, ao compor uma totalidade que reflete, a seu modo, um complexo dos desejos, censuras e expectativas angustiantes, mas é também metonímica, por prolongar o espaço psicoemocional. ${ }^{21}$ À medida da progressão da narrativa, o personagem regride, forjando realidades concretas como meio de projeção do espaço intrapsiquico. A leitura da inexistente carta enviada por Clara é um exemplo, pois é simultaneamente alucinatória e característica de um desejo infanto-juvenil. A isso se junta a interpretação das atitudes alheias como persecutórias, como se ele fosse alvo de intrigas e conluios generalizados.

21 Essa dupla derivação metafórica e metonímica foi tomada de empréstimo à concepção de Jean Laplanche sobre a constituição do eu como instância psiquica; cf. LAPLANCHE, 1985, p. 56-57. 
O duplo não consubstancia apenas tudo o que Golyádkin é, como no momento em que fala exatamente como o protagonista perante o médico:

Eu, Yákov Pietróvitch, senti simpatia à primeira vista pelo senhor e, pedindo a generosidade de me desculpar, contei com o senhor, atrevi-me a contar, Yákov Pietróvitch. Eu... aqui estou abandonado, Yákov Pietróvitch, sou pobre, sofri além da conta, Yákov Pietróvitch, e aqui tornei a sofrer. Ao saber que o senhor, com essas habituais qualidades inatas de sua alma maravilhosa, com o mesmo sobrenome que eu [...] (DOSTOIÉVSKI, 2011, p. 98).

mas tampouco como Golyádkin gostaria de ser, como afirma Renaux (1976), mas também como gostaria de ser tratado pelas outras pessoas, pois o sósia age de forma tão insolente, desrespeitosa e humilhante quanto o protagonista parece exigir que as pessoas sejam com ele: como inimigos. A inabilidade radical de Golyádkin, suas ações desastradas e sem tato algum demonstram não apenas a negação do bom senso, mas a afirmação de um desejo de ocupar o papel de bobo da corte, de um bufão, daquele que é admirado por um paradoxal excesso de déficit, por uma sandice espetacular: "- Tenha vergonha, meu caro senhor, tenha vergonha! - disse Andriêi Filippovitch num meio sussurro, com um ar inexprimivel de indignação. Proferiu a frase, pegou Clara Olsúfievna pela mão e afastou-se do senhor Golyádkin [...]" (DOSTOIÉVSKI, 2011, p. 55). ${ }^{22}$ Isso explica as atitudes de humilhação extremas a que é submetido pelo duplo, bem como seus esforços de se aproximar afetivamente dele. A cena final no salão de festas condensa a duplicidade do caráter exibicionista e ridículo, sua bufonaria, pois sua glorificação é tão-somente a subida para o cadafalso, de onde será enviado para o cemitério psíquico, o manicômio.

Como representação interna, na própria exposição literária, deste excesso caótico e fragmentado, vemos diversos planos e formas de concretização da duplicidade, como já indicamos ao início do texto. Uma delas é delineada pela polifonia das vozes, na qual a leitura de Bakhtin (1997, p. 213-219) insistiu muito acertadamente. A voz do narrador se entrelaça à do protagonista substituindo a de sua consciência moral, não se situando em nenhum momento para fora do campo perceptivo e do fluxo consciente do protagonista. Sendo não apenas acolhedora, mas também sarcástica, não é neutra em termos valorativos perante as escolhas e ações da personagem principal. Em função disso, a partir do surgimento do duplo não temos como nos certificar do que seja ou não fruto projetiva psicótica. Até as últimas páginas reina uma incerteza dramática quanto ao status de realidade do duplo, sendo este o motivo principal da crítica feita por Vassilon Bielinsk, que havia recebido com muito entusiasmo o primeiro livro de Dostoievski, Gente pobre (BIANCHI, 2009, p. 174-5). Em vez de um assim chamado "ensaio fisiológico", próprio da Escola Natural, cujo princípio fundante é retratar de forma realista, viva e literariamente convincente aspectos nodais das camadas sociais mais baixas, como o fez magistralmente Nikolai Gógol, nesse segundo livro de Dostoiévski temos um realismo sui generis, apoiado no mesmo estrato social, e movido por um páthos semelhante em seu desejo de dramatização da vida humana, mas essa âncora realista dará ensejo a um verdadeiro redemoinho de imagens, diálogos, pensamentos, decisões e impasses por assim dizer pós-românticos e pré-expressionistas, articulando a desagregação psiquica de Golyádkin a uma pequena epopeia, a uma travessia das vicissitudes da interioridade subjetiva em sua tensão não resolvida para com o plano social. Em vez de uma fisiognomia do ser social, agora temos algo como uma anatomia do ser psíquico-psicológico, tecida de forma pregnante pela proximidade e recusa do reconhecimento moral pelo outro. - É precisamente essa a caracteristica fundamental do que Adorno (1997e, p. 47) chamou de epopeia negativa.

O fato de o narrador assumir o caráter de duplo do protagonista por sua aproximação e descolamento como uma segunda voz é importante para compreendermos o sentido dramático da duplicidade em Dostoievski: ela somente se justifica no plano literário pelo fato de desafiar a identidade, o caráter unitário das personagens. A maior tensão

22 Todo esse complexo foi muito bem exposto por Bakhtin sob o conceito de carnavalização; Cf. Problemas da poética de Dostoiévski, p. $122-132$. 
dramática decorrente da existência do sósia consiste no pânico de Golyádkin em ser substituido por ele, ter sua identidade anulada, usurpada, completamente sugada: "Por fim, passou até a duvidar de sua própria existência [...]" (DOSTOIÉVSKI, 2011, p. 83); "Ai, Senhor, meu Deus! [...] E vai substituir um homem, aquele patife de marca maior vai substituir - vai substituir um homem como um trapo velho e não vai nem julgar que o homem não é um trapo velho. Ai, Senhor, meu Deus! Arre, que infelicidade" (DOSTOIÉVSKI, 2011, p. 131). Uma prótese de mim mesmo suficientemente pérfida para fazer-se passar como eu, absorvendo minha integridade moral, minhas atribuições, meu nome, meus valores, minha própria pessoa. Tal absorção negadora, porém, se dá atravessando um calvário de humilhações, sofrimentos, trapaças, exposições vexatórias, ridicularizações etc. Não se trata apenas de uma substituição objetiva, mas de uma destruição dolorosa, lenta e progressiva, em relação à qual o protagonista luta desesperadamente em sua autoafirmação obsessiva: "Eu, por exemplo, sou senhor de mim, e basta, não ligo para ninguém, e em minha inocência desprezo o inimigo. Não sou um intrigante e disto me orgulho. Sou puro, franco, asseado, agradável, complacente..." (DOSTOIÉVSKI, 2011, p. 93).

Simétrica a esse movimento de drenagem dolorosa da identidade, vemos a atitude invasiva, de penetração do outro em meu espaço, retirando a possibilidade de eu me fazer por mim mesmo sem esta invasão, tendente a se tornar inominável, absoluta. É interessante localizar o caráter "didático" da narrativa, ao percebermos a simetria entre a atitude de Golyádkin em querer invadir uma festa para a qual não apenas não foi convidado, quanto recusado, e a invasão acintosa de sua vida e de suas funções profissionais pelo sósia. Além disso, a todo instante ele se queixa de intrigas e perfidias supostamente articuladas por seus inimigos. Este caráter invasivo é tornado explícito na metáfora do sonho, quando milhares de duplos brotam do solo, infestando todo o espaço real e psíquico como seres que duplicam e anulam, invadem e ameaçam, substituem e caluniam, humilham e disso se orgulham.
Todo esse complexo de coisas demonstra a duplicidade significativa como extraida de um núcleo tão incompreendido da própria identidade, que termina por figurar positivamente a dramaticidade insuportável inerente ao esforço de se fazer por si mesmo. Quanto mais incompreendida, tanto mais a alteridade deverá ser recusada, e o esforço dessa rejeição pode culminar em uma exaustão psíquica, cujo resultado final é a presença regressiva, alucinatória e projetiva de um outro tão radicalmente outro que se constitui da coagulação destes restos não metabolizados. - Mais uma vez, vemos um momento didático da narrativa quando o médico diagnostica seu paciente como por demais solitário, avesso à vida em sociedade e a qualquer forma de prazer situado para além de sua casa, de seu próprio eu. O personagem é delineado como se esforçando continuamente por se sentir legitimado em sua inércia subjetiva, em se manter no plano horizontal e anônimo da existência. Diversas expressões denotam seu direito de ser apenas mais um, alguém legivel de um ponto de vista estatístico, numérico: "Ainda sorrindo, o senhor Golyádkin apressou-se em observar que the parecia que era como todo mundo, que vivia em casa, que seus divertimentos eram iguais aos de todo mundo..." (DOSTOIÉVSKI, 2011, p. 22); "ele era um homem como qualquer um, é claro que decente como todas as pessoas decentes..." (DOSTOIÉVSKI, 2011, p. 70). Trata-se de uma denegação contínua, recusas reiteradas de uma verdade, a saber: a identidade pessoal somente possui sentido na travessia sistemática de diferenças, no trânsito com o desejo do outro, com seu corpo, sua lógica e sua visão de mundo.

Considerando o caráter regressivo da mentalidade de Golyádkin, essa alteridade deve ser compreendida como se situando em um plano aquém da racionalidade discursiva, do embate ético-político, da valoração dialogada. Seguindo a perspectiva dos autores da Teoria Crítica, localizamos essa regressão no comportamento mimético. A mímesis é um fenômeno complexo, podendo ser estudado sob diversos pontos de vista e em muitos âmbitos de aplicação. Em termos gerais, o comportamento mimético é marcado por vínculos 
de semelhança, analogia, contiguidade, contágio, vinculação simbólica, parentesco, expressão somática, imagética e linguística de conteúdos psicoemocionais e outros processos agrupados sob os princípios da metáfora e da metonímica. Desde uma mera cópia literal até uma obra de arte abstrata podem ser entendidas como movidas por um impeto producente de imagens, representações e símbolos, todos eles fundados na correlação entre identidade e diferença concebidas aquém plano racional, abstrato, lógico e discursivo. A palavra mais usualmente empregada para traduzir "mímesis" é "imitação", mas nosso delineamento inicial já indica ser este termo por demais precário, cobrindo apenas uma parte dos fenômenos envolvidos na relação mimética.

A forma mais elementar de mímesis é o mimetismo, presente no comportamento automático e instintivo de alguns animais em se fazerem semelhantes ao meio ambiente ou fingirem-se de mortos. Não há nenhuma mediação entre si mesmo e o outro, entre "original" e "cópia", ambos os polos se fundindo no mesmo plano do agir. As primeiras ações imitativas das crianças também podem ser entendidas como mimetismo, as ecocinesias, quando o bebê replica o adulto imitando o ato de colocar a língua para fora. Pari passu a seu desenvolvimento psicomotor, a criança será capaz de imitar ações não apenas mais complexas quanto também alheias aos gestos já feitos espontaneamente por ela mesma. Cresce a intervenção da consciência neste processo e a imagem adquire certa autonomia perante o sujeito e o modelo da mímesis. Este estágio é especialmente relevante para nós, pois demarca o produto mimético como mediação entre sujeito e realidade, contendo uma ambiguidade fundamental do senso de identidade. A imagem produzida já se afasta suficientemente do sujeito e da realidade exterior, mas ainda contém muito da substância desses dois polos: o produto mimético "é" o sujeito e ao mesmo tempo "é" o mundo. ${ }^{23}$

Os rituais mágico-animistas de civilizações tribais podem ser interpretados como expres- sões desta imbricação de sujeito e objeto no plano da imagem mimética. Freud concebeu a magia como uma técnica de influência nos processos naturais e sociais a partir do conceito de onipotência dos pensamentos, quando qualquer duplicação simbólica (desde a imagem mais imediatamente fiel até relações linguísticas mais distantes) é vivenciada como tendo poder e influência sobre a realidade. Bonecos de vodu, danças evocando a chuva, carrancas, pinturas de animais de caça, encenações da morte de adversários, recitação de mistérios e ações de seres sobrenaturais, manipulação de nomes e restos corporais alheios: tudo isto se insere em um complexo de ação cuja lógica reside na percepção intima de a representação mimética influenciar diretamente uma porção da realidade, independente de sua localização espacial e de sua determinação cronológica. O ser do sujeito e o ser da coisa encontram-se imbricados essencialmente neste meio do caminho da representação mimética ${ }^{24}$.

Tal como nos diz Hegel em seus Cursos de estética (1986), a origem da arte é a religião, quando a transcendência das forças cósmicas se entrelaçava à beleza, à expressividade e ao impacto mimético das cores, das figuras, dos sons, dos movimentos corporais, da narrativa etc. Somente na antiguidade grega a força imagética da arte experimentou uma secularização expressiva, embora ainda ligada ao complexo motivacional ético-político. Com o desencantamento do mundo na modernidade, a arte pôde se desvencilhar mais substancialmente das outras esferas da cultura e perseguir sua autonomia de forma enfática. A pintura mais abstrata, a música mais dodecafônica e a poesia mais concreta, porém, ainda são passiveis de compreensão por meio da mímesis, pelo modo como toda a configuração final das obras resulta na assimilação, mutabilidade, desvio, ruptura, reelaboração dos códigos, modelos de produção e recepção artísticas anteriores. A mímesis deixa de ser pautada no âmbito plástico imediato das obras, situando-se no complexo 
motivacional gerador de cada artefato, desde as ressonâncias psicoemocionais dos artistas até as considerações críticas sobre o mundo da arte, o universo da crítica e da reflexão filosófica, a contraposição às mercadorias culturais etc.

Muito da dramaticidade da narrativa de O duplo é compreensivel a partir da ideia de uma regressão mimética, àquele estágio de desenvolvimento psicoemocional em que a duplicação imagética agrega grande parte de nossa identidade, de nosso ser mesmo, de nossa substância. Em vez de a imagem ser índice de progresso na diferenciação entre sujeito e realidade, opera como suporte da desagregação psíquica, de sua cisão interna, quando então o sujeito duplica a si mesmo como o último lance na tentativa e de manter seu senso de identidade. Sob o influxo de um excesso contraditório inassimilável internamente, torna-se impossivel o salto para a alteridade social, linguisticamente mediada, que demanda o enfrentamento do jogo de forças da arbitrariedade dos valores, tendo como consequência a necessidade de produção de uma alteridade por e em si mesmo, dispensando e muitas vezes de forma plena o suporte da realidade empirica.

Além desta regressão ao plano da mimesis alucinatória, vemos também a insistência do protagonista em utilizar "fórmulas mágicas" visando apreender e anular o curso da realidade em palavras de incentivo e de negação do acontecido. Embora não faça uso de mecanismos ritualisticos de forma literal, a linguagem é empregada como depositária do desejo de atuação direta na realidade, realizando uma conjuração de forças à distância, pretendendo ultrapassar a necessidade de um agir concreto, sempre parcial e precário. Por fim, vemos o protagonista invocar uma espécie de poder mágico de seu olhar para destruir e reduzir a pó todos os seus inimigos. O gesto é tomado como magicamente poderoso e total, sem resto, desconsiderando a racionalidade das partes e etapas de constituição da vida empiricamente experimentada. Esse movimento de totalização já está presente nas primeiras formas de assimilação mimética do outro, percebido como aprisionado na imagem para além da necessidade de somar forças e de atravessar etapas, tal como diz Freud com o conceito de onipotência dos pensamentos.

Restaria ainda por compreender todo o romance como uma representação mimética das aventuras do Sr. Golyádkin, um plano de representação narrativa e literária. Como esta dimensão não chega a ser propriamente um tema da obra, deixaremos para abordá-la quando de nossa análise ulterior das Memórias do subsolo. Gostaríamos apenas de pontuar um aspecto dialógico não ressaltado por Bakhtin: a mescla das vozes do narrador e do protagonista, a indefinição deliberada do fluxo de consciência e do narrativo situa a nós, leitores, como duplos, tanto do narrador quanto do protagonista. A insistência irônica de se tratar de uma história verídica quer insinuar que nossa posição na leitura é voyeurista, comprazendo-se nas vias tortuosas e sofridas dessa trajetória, um verdadeiro contorcionismo psíquico de quem perdeu seu ponto de apoio nuclear. Somos situados em um lugar a partir do qual nos regozijamos com a impossibilidade, por principio, de saída, a não ser a do blefe pela projeção alucinatória. Essa atitude voyeurista, porém, somente se consuma de forma cabal em outro plano de duplicidade: na segunda leitura do romance, pois na primeira ainda não está claro o estatuto do duplo: se faz parte de uma literatura fantástica, se se trata de alucinação ou de uma zombaria muito bem arquitetada por outros personagens para destruir o protagonista. Ao se reler o "poema petersburguense", entretanto, tendo clareza da progressiva falência psicoemocional, ganhamos uma solidez em nossa compreensão da trama, permitindo-nos vivenciar nosso voyeurismo, que beira o sádico, de forma bem mais clara. (Em certos momentos, é desconcertante perceber que tendemos a nos identificar com o sósia...)

Um aspecto relevante da psicologia do protagonista é a inervação psiquica no âmbito corporal. De forma análoga à regressão acintosa na projeção alucinatória, o corpo deverá agregar uma série de tensões dramáticas psicoemocionais, ligadas essencialmente ao trânsito com a alteridade, particularmente à do duplo. Os dois 
protagonistas se enfrentam fisicamente em diversas circunstâncias, como o aperto de mão em um ambiente de trabalho (em que o sósia retira os dois dedos e cospe neles), quando Golyádkin tenta agarrar o sósia ao subir na carruagem, quando este aperta sua bochecha na repartição e mais tarde quando joga por cima dele seu capote. Todos esses momentos demarcam as maiores tensões emocionais decorrentes da projeção alucinatória, uma vez que a dor e a proximidade física lhe conferem um grau e um tipo de realidade incapaz de ser digerida pela fórmula mágica preferida pelo protagonista: "isso não há de ser nada". O corpo demarca uma interseção por demais concreta entre a interioridade autocomplacente e as especulações sobre o outro como inimigo, intrigante, ameaçador: trata-se de uma ponte a desmentir o juízo geral-abstrato de tudo consistir apenas em especulações e teorias conspiratórias. A dor moral de ofender e ser ofendido, de humilhar e ser humilhado - constante no texto -, é traduzida regressivamente no sofrimento corpóreo, em uma vergonha fisica de ter seu corpo exposto a uma visualidade incompativel com a sobriedade do foro intimo.

Essa figura mediadora do corpo encontra uma representação eloquente quando Golyádkin, em um dos instantes máximos de aflição pela perda de sua identidade, afirma se dispor a decepar um dedo em troca da volta de sua singularidade (com o desaparecimento do sósia, como se vê na página 128), ou seja, ele oferece sua integridade física em sacrifício por sua integridade como indivíduo, como pessoa, como eu. O membro amputado conjuraria a duplicidade e morreria com ela: tal como o duplo, é também um prolongamento da individualidade e pela dor que acarreta assume o status de indivíduo de inteiro teor, agregando a substância de um ente oferecido em sacrifício. - Em sua leitura sobre a dialética do processo de racionalização ocidental, Adorno e Horkheimer interpretam o ritual do sacrificio como uma relação de troca em que o sangue individual, seja do primogênito, de uma virgem ou de um cordeiro, reflui para o corpo coletivo. Este, engrandecido pela confluência de forças vitais, atua como fonte de direito próprio de um poder de enobrecimento, elevação e dignidade, conferindo significado e razão de ser a tudo e a todos. Ao longo das sucessivas fases desta ritualistica, cada individuo é ensinado a realizar por si mesmo este sacrificio, interiorizando o sofrimento como preço inalienável para a conquista da realização pessoal. A cada dia de trabalho, a cada prazer desperdiçado, a cada desilusão com os objetos de desejo, mais se torna claro o quanto esta relação de troca entre a concretude do presente a promessa de felicidade futura é um embuste, um logro, uma miragem. ${ }^{25}$ - Golyádkin sabe que sua oferta de sacrifício é ficcional e irrealizável, mas é também indice de uma verdade em outro plano, não apenas do desespero aflitivo do protagonista, mas sim da vivência intima do fato de a exclusão maximal do outro em mim significar uma castração de minha identidade: Golyádkin sempre foi apresentado como cortando a presença da alteridade, excluindo sua concretude por demais indigesta e incômoda para o plano abstrato/total da autoidentidade. Nessa metonimia do sacrificio do dedo, tem-se uma assunção involuntária de a presença do outro ser muito mais constitutiva de mim do que nas representações de reconhecimento ético.

Em resumo, vemos que o romance $O$ duplo corporifica a idéia de uma "epopéia negativa" pelo modo como dramatiza a cisão entre indivíduo e coletividade, entre o eu e o outro, figurada como uma cisão catastrófica no interior da subjetividade. Em vez de o indivíduo se constituir progressivamente na travessia da objetividade social e natural, como vemos na Odisséia, temos um movimento inverso, interiorizado, demonstrando o quanto a subjetividade sob o império das relações sociais modernas constitui-se como um enovelamento contraditório, múltiplo, fragmentária, de sedimentos sociais. A força da poética de Dostoiévski demonstra o quanto a contradição e a impossibilidade de trânsito pleno com a alteridade social são um componente de primeira grandeza da própria noção de sujeito. 


\section{Referências}

ADORNO, Theodor W. Ästhetische Theorie. In: Gesammelte Schriften: v. 7. Frankfurt am Maln: Suhrkamp, 1997. (a)

ADORNO, Theodor W. "Aufzeichnungen zu Kafka". In: Prismen. Kulturkritik und Gesellschaft. Gesammelte Schriften: v. 10. Frankfurt am Main: Suhrkamp, 1997. p.254-88. (b)

ADORNO, Theodor W. Mahler. Eine musikalische Physiognomik. In: Gesammelte Schriften: v. 13. Frankfurt am Main: Suhrkamp, 1997. p.149-320. (c)

ADORNO, Theodor W. Minima Moralia. In: Gesammelte Schriften: v. 4. Frankfurt am Maln: Suhrkamp, 1997. (d)

ADORNO, Theodor W. Noten zur Literatur. In: Gesammelte Schriften: v. 11. Frankfurt am Maln: Suhrkamp, 1997. (e)

ADORNO, Theodor W. Philosophie der neuen Musik. In: Gesammelte Schriften: v. 12. Frankfurt am Main: Suhrkamp, 1997. (f)

ADORNO, Theodor W. "Sobre a relação entre psicologia e sociologia". Tradução de Verlaine Freitas. São Paulo: UNESP, 2015. p.71-135. (g)

ADORNO, Theodor Wiesengrund; HORKHEIMER, Max. Dialektik der Aufklärung. In: ADORNO, Theodor Wiesengrund. Gesammelte Schriften: v. 3. Frankfurt am Maln: Suhrkamp, 1997.

BAKHTIN, Mikhail: Problemas da poética de Dostoiévski. Tradução de Paulo Bezerra. Rio de Janeiro: Forense Universitaria, 1997.

BENJAMIN, Walter. "Der Erzähler". In: Gesammelte Schriften: v. II. Frankfurt am Main: Suhrkamp, 1997. p.438-464.

BIANCHI, Fátima. "Posfácio". In: DOSTOIÉVSKI, Fiódor M. Gente pobre. Tradução de Fátima Bianchi. São Paulo: Editora 34, 2009. p. 174-83

BREGER, Louis. Dostoevsky: The Author as Psychoanalyst. Nova lorque: Nova lorque University Press, 1989.

CARROL, John. Out from the Crystal Palace. Stirner, Nietzsche and Dostoevsky. Londres: Routledge and Kegan Paul, 1988.

CHIZHEVSKY, Dmitri. "The Theme of the Double in Dostoevsky". In: WELLEK, René (org.). Dostoevsky. A Collection of Critical Essays. New Jersey: Prentice-Hall, 1962. p. 112-129.

CUNNINGHAM, David. "After Adorno: The Narrator of the Contemporary European Novel". In: CUNNINGHAM, David; MAPP, Nigel (ed.) Adorno and Literature. Londres: Continuum, 2006. p. 188-200.

DOSTOIÉVSKI, Fiódor M. Crime e castigo. Tradução de Paulo Bezerra. São Paulo: Editora 34, 2001.

DOSTOIÉVSKI, Fiódor M. Memórias do subsolo. Tradução de Boris Schnaiderman. São Paulo: Editora 34, 2000.

DOSTOIÉVSKI, Fiódor M. O duplo. Poema petersburguense. Tradução de Paulo Bezerra. São Paulo: Editora 34.
FOSTER, Roger. "Adorno on Kafka: Interpreting the Grimace on the Face of Truth". New German Critique, [S. l.], n. 118, p.135-98, Winter. 2013. https://doi. org/10.1215/0094033X-1812613.

FREITAS, Verlaine. "Kafka: A opacidade semântica do mundo. Um comentário de 'Anotações sobre Kafka', de Theodor Adorno". Artefilosofia, Ouro Preto, MG, v. 23, p. 123-146, 2017.

FREUD, Sigmund. "Dostojewski und die Vatertötung". In: Gesammelte Werke v. XIV. Frankfurt am Main: Fischer Verlag, 1999. p.397-417. (a)

FREUD, Sigmund. "Eine Kindheitserinnerung des Leonardo da Vinci". In: Gesammelte Werke: v. XI. Frankfurt am Main: Fischer Verlag, 1999. p. 127-211. (b)

FREUD, Sigmund. Totem und Tabu. In: Gesammelte Werke: v. XII. Frankfurt am Main: Fischer Verlag, 1999. (c)

HEGEL, Georg W. F. Vorlesungen über die Ästhetik. Frankfurt am Main: Suhrkamp, 1986.

LAPLANCHE, Jean. Vida e morte em psicanálise. Tradução de Cleonice Paes Barreto Mourão e Consuelo Fortes Santiago. Porto Alegre: Artes Médicas, 1985.

LUKÁCS, Georg. "Dostoevsky". In: WELLEK, René (org.). Dostoevsky. A Collection of Critical Essays. New Jersey: Prentice-Hall, 1962. p. 146-58.

LUKÁCS, Georg. Die Theorie des Romans. Ein geschichtsphilosophischer Versuch über die Formen der großen Epik. Darmstadt: Hermann Luchterhand, 1971.

NIETZSCHE, Friedrich W. "Die Fröhliche Wissenschaft". In: Kritische Studien Ausgabe. Vol. 3. München: De Gruyter, 1999. p. 343-652. (a)

NIETZSCHE, Friedrich W. Zur Genealogie der Moral. In: Kritische Studien Ausgabe. Vol. 3. München: De Gruyter, 1999. p. 246-412(b)

NIETZSCHE, Friedrich W. Götzen-Dämmerung. In: Kritische Studien Ausgabe: v. 2. München: De Gruyter, 1999. (c)

NIETZSCHE, Friedrich W. Menschliches, Allzumenschliches. In: Kritische Studien Ausgabe: v. 2 München: De Gruyter, 1999. (d)

PARIS, Bernard J. Dostoevsky's Greatest Characters: A New Approach to "Notes from Underground," "Crime and Punishment," and "The Brothers Karamazov". Nova lorque: Palgrave MacMillan, 2008. https://doi. org/10.1057/9780230610569.

PIAGET, Jean A. Formação do símbolo na criança: Imitação, jogo, sonho, imagem e representação. Tradução de Dias, A. e Oiticica, C. M. Rio de Janeiro: LTC, 2014.

RENAUX, Sigrid. "Dostoiévski: A duplicidade na estrutura narrativa de O duplo". Letras, Curitiba, n. 25, p. 347-400, jul. 1976. https://doi.org/10.5380/rel.v25io.19558.

SAFATLE, Vladimir. "Destituição subjetiva e dissolução do eu na obra de John Cage". In: RIVERA, Tânia; SAFATLE, Vladimir. Sobre Arte e Psicanálise. São Paulo: Escuta, 2006. p. 163-196.

SCHILLER, Friedrich. "Über naive und sentimentalische Dichtung". Hamburg: Reclam, 2002. 
SOUZA, Claudia Franco. Nietzsche \& Dostoiévski. Lisboa: Apenas Livros, 2016.

STELLINO, Paolo. Nietzsche and Dostoevsky. On the Verge of Nihilism. Berna: Peter Lang, 2015. https://doi. org/10.3726/978-3-0351-0860-6.

TCHERNICHÉVSKI, Nikolai. "The Antropological Principle in Philosophy". In: Selected Essays. Tradução de M. Grigoryan. Honolulu: University Press of the Pacific, 2002. p. [1-29].

TERRAS, Victor. Reading Dostoevsky. Wisconsin: The University of Wisconsin Press, 1998.

TODOROV, Tzvetan. "Le jeu de l'altérité: Notes d'un souterrain". In: Poétique de la prose. Paris: Éditions du Seuil, 1971. p. 133-160.

\section{Verlaine Freitas}

Doutor em Filosofia pela Universidade Federal de Minas Gerais (UFMG) em Belo Horizonte, MG, Brasil; Estágio de Pós-doutorado na University of Windsor, Canadá (2011). Professor Titular da UFMG em Belo Horizonte, MG, Brasil e pesquisador do CNPq.

\section{Endereço para correspondência}

Verlaine Freitas

Universidade Federal de Minas Gerais

Av. Pres. Antônio Carlos, 6627

Pampulha, 31270901

Belo Horizonte, MG, Brasil 